\title{
Sciendo
}

Administration, vol. 67, no. 3 (2019), pp. 1-5

doi: 10.2478/admin-2019-0018

\section{The structural failure of regional planning in Ireland: Introduction}

\author{
Chris van Egeraat \\ Department of Geography, Maynooth University, Ireland
}

Regional development in Ireland has historically been unbalanced. Although the original causes were linked to the activities of colonial administration, it is partly due to a structural failure of regional planning. The institutional structures in general have been historically centralised and disaggregated and, up to the 2000s, the planning institutions and legislative arrangements were underdeveloped.

Back in the 1990s there was no national planning policy (see Table 1). We adopted very much a business-as-usual model. There was no regional planning in a spatial sense. The Planning and Development Act of 1963 was a relatively modest piece of legislation. There were very few EU directives impacting directly upon planning, the first one being the Environmental Impact Assessment, which came into force in the 1980s. The main focus at this time was on economic concerns. We had just one statutory planning guideline. Ireland had a total of eightyeight planning authorities for 3.7 million people and one national planning authority, An Bord Pleanála. There were very few judicial reviews of planning decisions.

A lot has changed since the 1990s. The first officially adopted national spatial planning policy was launched in 2002 in the form of the National Spatial Strategy. Since 2008 we have a National Planning Framework (NPF), directly linked to a capital investment plan - the Department of Finance and the Department of Housing, Planning and 
Local Government working in concert with each other. From 2009 the three regional assemblies were required to develop regional spatial and economic strategies. The Planning and Development Act, 2000, is considerably more complex than its 1963 predecessor, and has been subject to 944 amendments. A considerable number of EU directives have been added. The focus of planning has been broadened to include, amongst others, economic, environmental, cultural and housing concerns. The minister has issued over thirty statutory guidelines under Section 28 of the Planning Act. The number of planning authorities has been significantly reduced to thirty-one. There are now three regional assemblies and new regulatory bodies that impact directly on the planning process, including the Environmental Protection Agency and the Land Development Agency. In 2019 there were over 150 judicial reviews on planningrelated matters pending. Finally, following recommendations from the Mahon Tribunal, in 2019 the minister established the Office of the Planning Regulator with, among other powers, the function to oversee the preparation of spatial plans.

Notwithstanding these changes, problems remain. The National Spatial Strategy is generally considered to have been unsuccessful, mainly due to a lack of implementation driven by shortcomings in governance. An analysis of these shortcomings and lessons for the NPF were the subject of a previous mini-symposium published in this Journal (Ó’Riordáin \& van Egeraat, 2016). The symposium in this issue is more focused on regional planning, while at the same time adopting a more historical analysis, revisiting regional planning in Ireland as far back as the 1940s. The symposium draws on papers presented at the conference 'City-led Regional Development', organised by the Regional Studies Association, Irish Section. ${ }^{1}$ The conference specifically addressed the NPF strategy of stimulating regional development by concentrating resources in a select number of second-tier urban centres.

The first paper, by James Walsh, provides a historical overview of spatial planning in Ireland. It reviews both visions and plans for regional development that have been proposed since the 1940s. The review demonstrates that there have been several attempts to articulate visions and plans for Ireland. The importance of context and

1 'City-led Regional Development', annual conference of the Irish Section of the Regional Studies Association, Institute of Technology Sligo, 9 September 2018. 
Table 1: Planning in Ireland before and after 2000

\begin{tabular}{|c|c|}
\hline $1990 s$ & 2019 \\
\hline No national planning policy & A national planning framework \\
\hline No regional planning & $\begin{array}{l}\text { Regional spatial and economic } \\
\text { strategies }\end{array}$ \\
\hline Planning and Development Act, 1963 & $\begin{array}{l}\text { Planning and Development Act, } 2000 \text { - } \\
944 \text { amendments since } 2000\end{array}$ \\
\hline $\begin{array}{l}\text { Few EU directives impacting directly } \\
\text { on planning }\end{array}$ & $\begin{array}{l}\text { A range of EU directives: EIA, SEA, } \\
\text { Habitats, WFD, Noise, Public } \\
\text { Participation, Services, Aarhus, and so } \\
\text { forth }\end{array}$ \\
\hline $\begin{array}{l}\text { Key concern: Economic } \\
\text { development }\end{array}$ & $\begin{array}{l}\text { Key concern: Sustainable development, } \\
\text { environmental protection, climate } \\
\text { adaptation and emissions reduction, } \\
\text { housing delivery, rational delivery of } \\
\text { public services }\end{array}$ \\
\hline 1 statutory planning guideline & $\begin{array}{l}\text { Over } 30 \text { ministerial guidelines and } \\
\text { directives }\end{array}$ \\
\hline $\begin{array}{l}88 \text { planning authorities } \\
\text { An Board Pleanála }\end{array}$ & $\begin{array}{l}31 \text { planning authorities } \\
3 \text { regional assemblies } \\
\text { An Bord Pleanála } \\
\text { Environmental Protection Agency, Land } \\
\text { Development Agency }\end{array}$ \\
\hline $\begin{array}{l}\text { Few judicial reviews of planning } \\
\text { decisions }\end{array}$ & $\begin{array}{l}\text { Over } 150 \text { judicial reviews on planning- } \\
\text { related matters }\end{array}$ \\
\hline
\end{tabular}

Source: Based on Cussen (2019).

the likelihood of a plurality of visions at different times is evident. It also demonstrates that the visions of leading politicians may not always be closely aligned with those of professional planners - this was clearly evident in the 1940s and most recently in the final months of preparing the NPF.

The political ideological context for state engagement with regional planning has changed profoundly from a state-led, interregional welfare redistribution approach to a more neo-liberal and entrepreneurial ideology that provides for different formulations of opportunities and threats in each region. On a broader scale globalisation has become an increasingly important source of 
differentiated transformation of regions, and has resulted in changes in the relationship between Dublin and the rest of the country at different times. The practice of planning, including the methodologies employed and the roles of individual planners, has evolved from technocratic prescription and shaping to more inclusive and collaborative facilitation of plan-making.

The author expresses the hope that the NPF will bring about radical changes that are required for a new epoch between now and 2040. But he stresses that much will depend on the capacity to develop leadership structures to promote and implement new pathways that can cater for diversity and involve partnerships between the public, private and voluntary civic sectors.

The second paper, by Proinnsias Breathnach, focuses on the impact of the 'Buchanan report', published fifty years ago (Colin Buchanan and Partners, 1968). This consultancy report included an assessment of the growth potential of Irish regions, the identification of possible development centres and the formulation of development policy proposals, including measures required for implementation of these proposals. The main thrust of the report was the concentration of the great bulk of new industrial employment creation in Dublin and eight proposed growth centres. The government rejected these proposals. The paper reviews the implications for the regional planning process in Ireland of the Buchanan report experience, arguing that failure to learn from this experience served to undermine the National Spatial Strategy, with a similar fate likely for the NPF. According to the author, the key elements of the Buchanan proposals - cultivation of the main regional centres as self-sustaining complexes of interdependent enterprises, creation of strong regional governance structures, effective coordination of public sector agencies at regional level, and radical reorganisation of the local government system remain as relevant today as they did then.

The starting point for the final paper, by Des McCafferty, is the observation that both the Buchanan report proposals and the National Spatial Strategy have sought to identify population centres that should be prioritised for investment, notably Ireland's second-tier cities. Since neither visions were implemented, McCafferty examines how the urban hierarchy has evolved over the last sixty years. Such a perspective provides an understanding of the costs of failing to plan for territorial development. The detailed empirical analysis shows that the failure to implement the approach has meant that second-tier centres in Ireland have performed poorly in terms of population 
growth. There has been no discernible convergence between secondtier cities and Dublin, but the gap between them and the large towns has narrowed considerably. The paper clearly highlights the challenges Ireland is facing in meeting the NPF target of concentrating half of the population growth from 2018 to 2040 within the five main cities.

\section{References}

Colin Buchanan and Partners. (1968). Regional studies in Ireland. Dublin: An Foras Forbartha.

Cussen, N. (2019). The Office of the Planning Regulator: Context, overview, outlook. Paper presented at 'City-led Regional Development', annual conference of the Irish Section of the Regional Studies Association, Institute of Technology Sligo, 9 September 2018.

Ó'Riordáin, S., \& van Egeraat, C. (2016). The National Spatial Strategy: Lessons for implementing a National Planning Framework. Administration, 64 (4), 5-21. 